\title{
Dakwah Sebagai Ujung Tombak Penanganan Radikalisme Agama di Indonesia
}

\author{
Muhammad Said \\ Mahasiswa Pascasarjana Program Doktor UIN Sunan Kalijaga \\ siadmoch1987@gmail.com
}

\begin{abstract}
Radicalism in Islam gives depict about the existing of group that exclusive and militant. The attitude without compromise, not respect other people who different faith and crude are "the truth" that they chose. They do not care the destructive reason of their action. Moreover, they do the crude by the naming of religion whereas they are not well confessor of religion. Look at this problem, the writer feels to obligate to reflect back, why Islam is the religion "rahmatan lil 'alamin", the religion that loved the peace is becoming the object of all the disturbance action in radical sight. There are two factors of arisen Radical Islam in Indonesia. The first internal factor occurs because the existing of diversion the religion norms. Secondly, external factor for the Muslim whether is occurred by controller or hegemony from western does not support toward applying of Islamic law in the life. The obligation of the rule and public organization of preaching in Indonesia for together handles the radicalism problem of religion so that the goal of preaching to share the conciliation messages, Islam as the welfare religion and the mercy can realize for all the people.
\end{abstract}

Keywords: Radicalism of Religion, Peacefull Religion, Islam, Rahmatan lil 'alamin. 


\section{Pendahuluan}

Dalam konstelasi kehidupan di dunia ini manusia tentunya tidak bisa terlepas dari apa yang dinamakan dengan agama. Hal tersebut dikarenakan agama sangat inhern dalam kehidupan sosial manusia dengan segala dinamika yang ada. Hal tersebut mengandung arti bahwa manusia dalam aktivitasnya tidak bisa terlepas dari nilai-nilai agama yang ada di dalamnya. Dalam hal ini Islam adalah agama bagi umat manusia yang di dalamnya memuat pesan yang bersifat universal dan abadi dikarenakan ajarannya akan selalu mengikat selama dalam masa taklif (mukallaf). Konsekuensi tersebut tertuang dalam suguhan konsepsi hukum Islam yang menjamin perbaikan dan peningkatan kehidupan umatnya baik di dunia maupun di akhirat. Islam adalah pandangan hidup yang lengkap (kaffah), membimbing sesuai petunjuk-petunjuk Allah Swt., sebagaimana yang disampaikan oleh Rasul-Nya, Muhammad Saw. ${ }^{1}$

Secara praktis, Islam menuntut para pemeluknya untuk senantiasa menyeru, mengajak, dan menyampaikan ajarannya agar apa yang menjadi pesan agama dapat disebarluaskan ke seluruh alam semesta. ${ }^{2} \mathrm{Hal}$ tersebut merupakan suatu kewajiban yang harus dilaksanakan oleh setiap umat Islam, yang tentunya dalam penyampaian misi dakwah yang diterapkannya dalam rangka mengajak manusia kepada ajaran Islam haruslah mengacu pada apa yang telah dicontohkan oleh Rasulullah Muhammad Saw. ${ }^{3}$ Mengenai kewajiban menyampaikan dakwah Islam, Allah Swt. berfirman dalam al-Qur'an Surat an-Nahl ([16]: 125):

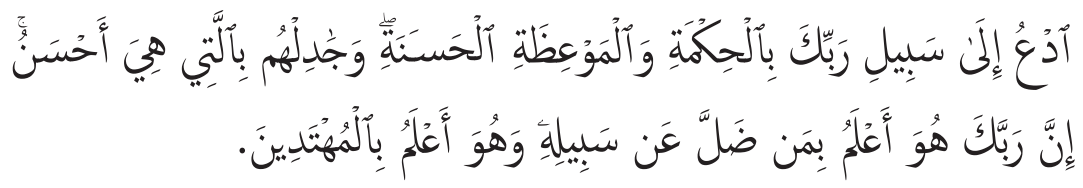

1 Begum A’isyah Bawany, Mengenal Islam Selayang Pandang, terj. Machnun Husein (Jakarta: Bumi Aksara, 1994), 5.

2 Konsep tentang menyeru, mengajak, menyempaikan, dan mempengaruhi tersebut yang kemudian dinamakan dengan dakwah. Lihat pengertian dakwah Awaludin Pimay, Metodologi Dakwah: Kajian Teoritis dari Khazanah al-Quran (Semarang: Rasail, 2006), 2 .

3 Mohammad Natsir, Fiqhud Da’wah (Jakarta: Media Da’wah, 2000), 125. 
Serulah (manusia) kepada jalan Tuhan-mu dengan hikmah, dan pelajaran yang baik dan bantahlah mereka dengan cara yang baik. Sesungguhnya Tuhanmu Dialah yang lebih mengetahui tentang siapa yang tersesat dari jalan-Nya dan Dialah yang lebih mengetahui orang-orang yang mendapat petunjuk.

Hermeneutika kata $u d$ 'u yang selanjutnya ditafsirkan dengan 'seruan' yang merupakan fi'il amr, yang dalam kaidah ushul fikih merujuk kepada hukum wajib mengindikasikan bahwa dakwah mutlak harus direalisasikan di dalam setiap sendi-sendi kehidupan. ${ }^{4}$ Islam adalah agama dakwah yang mengandung arti bahwa keberadaanya di muka bumi ini adalah dengan disebarluaskan dan diperkenalkan kepada seluruh umat melalui aktivitas dakwah, bukan dengan paksaan, kekerasan, dan tidak pula dengan kekuatan pedang. Hal ini dapat kita pahami, karena Islam sendiri adalah agama pembawa perdamaian, agama cinta kasih, agama pembebasan dari belenggu perbudakan, dan mengakui hak dan kewajiban setiap individu. Ini berarti anggapan para oreientalis yang selama ini mengatakan Islam adalah agama yang kejam, menakutkan dan dikenal dengan radikalisme, adalah tidak benar. Pernyataan demikian tentunya tidak sesuai karena dalam surat al-Baqarah ([2]: 256), Allah berfirman sebagai berikut:

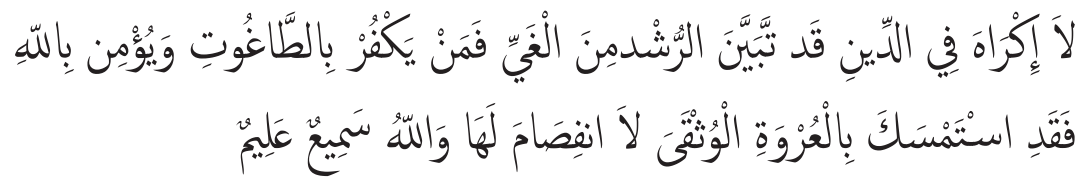

Tidak ada paksaan untuk (memasuki) agama (Islam); Sesungguhnya telah jelas jalan yang benar daripada jalan yang sesat. karena itu Barangsiapa yang ingkar kepada Thaghut dan beriman kepada Allah, Maka Sesungguhnya ia telah berpegang kepada

4 Kewajiban berdakwah sesuai dengan Q.S. an-Nahl ([16]: 125) merupakan kewajiban mutlak (absolut). Hal tersebut karena para ulama telah bersepakat mengenai hukum wajibnya, hanya saja di antara mereka ada yang mengatakan wajib 'ain (berlaku universal/setiap orang), dan ulama lain mengatakan wajib kifayah (dalam arti apabila alam satu kelompok sudah ada yang menjalankanya, maka gugur kewajiban tersebut). Aminuddin Sanwar, Pengantar Ilmu Dakwah (Semarang: Fakultas dakwah, 1986), 34. 
buhul tali yang Amat kuat yang tidak akan putus. dan Allah Maha mendengar lagi Maha mengetahui.

Fenomena yang menarik perhatian di Indonesia yaitu ketika dalam kondisi masyarakat Islam dengan berbagai problematika dakwahnya, maka tak henti-hentinya muncul pemikir-pemikir sejak zaman klasik hingga sekarang, di mana di dalamnya lahir aliran-aliran yang menaruh perhatian besar terhadap pelaksanaan dakwah Islamiah. Akan tetapi dalam realitanya, mereka di dalam penyampaian ajarannya cenderung ortodoks, kaku, dan kolot, bahkan nilai-nilai ajaran yang disampaikannya terkesan jumud dan mandeg di tempat tidak bisa sesuai dengan dinamika kehidupan zaman. Dalam menerjemahkan ayat-ayat al-Qur'an pun hanya dikaji secara tekstual, tidak mengenal istilah hermenutika atau tafsir. Ironinya, tidak berhenti sampai di situ saja, akan tetapi mereka menginginkan ajaran Islam diterapkan di dalam setiap lini kehidupan (kaffah) dengan cara yang mereka benarkan, tanpa mengambil dari manhaj hukum yang semestinya. Bukankah hal demikian akan dapat mengganggu keharmonisan dalam kehidupan?

Beberapa golongan yang tergabung dalam Islam radikal seperti Darul Islam (DI), Hisbut Tahrir Indonesia (HTI), Negara Islam Indonesi (NII), dan Ikhwanul Muslimin (IM) mereka cenderung bersikap eksklusif dan hanya mengakui kebenaran mereka sendiri. Mereka menganggap orang kafir adalah musuh yang harus mereka perangi, tidak hanya itu saja, orang Muslim lain yang tidak sehaluan dengan mereka pun tak luput mendapat predikat sebagai orang-orang yang sesat. Doktrin yang mereka usung adalah takfiri yaitu sikap yang selalu mengkafirkan golongan lain yang berada di luar kelompoknya. Salah satu tokoh Ikhwanul Muslimin yang pemikiranya sangat berpengaruh dalam menyulut radikalisme agama yang ada adalah Sayyid Qutub. Ia berpendapat "Barang siapa yang memutuskan suatu hukum (termasuk di dalamnya menjalankan pemerintahan) dengan hukum selain al-Qur'an berarti ia telah kafir." Pemikiran tersebut tentunya berpijak pada interpretasi dari Q.S. al-Ma'idah ([5]: 44) sebagai berikut: 


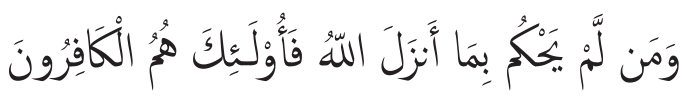

Barangsiapa yang tidak memutuskan menurut apa yang diturunkan Allah, maka mereka itu adalah orang-orang yang kafir.

Berawal dari pemikiran tersebut, aliran Islam radikal telah menjustifikasi diri seperti para hakim dan aparat pemerintahan yang ada, yang tidak menggunakan hukum syariat adalah halal dibunuh. Sikapsikap demikianlah yang tentunya dapat membawa mereka ke dalam faham keberagamaan yang cenderung kaku dan kolot. ${ }^{5}$ Selanjutnya sikap tersebut telah mereka ejawantahkan dalam praktik kehidupan, sebagai suatu contoh mereka menganggap harta yang dimiliki oleh orang lain adalah sah untuk dimiliki organisasinya. Bahkan dengan cara-cara yang tidak Islami seperti penipuan, pencurian, bahkan dengan cara-cara kekerasan sekalipun, mereka mengklaim bahwa harta itu adalah milik Allah. ${ }^{6}$

Radikalisme dalam Islam memberikan gambaran adanya kelompok yang ekslusif dan militan. Sampai batas tertentu, seperti yang disebutkan di atas, ada kesan bahwa kelompok itu menganggap orang lain sebagai musuh. Yang dimasukkan dalam golongan musuh itu tidak hanya mereka yang berbeda agama, melainkan orang-orang seagama yang mereka anggap telah melakukan banyak kemaksiatan atau diam saja ketika kemaksiatan ada di sekeliling mereka. Klaim kebenaran tunggal juga melekat dalam ingatan para golongan ini.

Radikalisme agama yang akhir-akhir ini muncul kepermukaan seakan menyiratkan ketidakpuasan suatu kaum dalam adaptasinya dengan yang lain. Hal tersebut menyangkut praktik kehidupan (mu'amalah) dan peribadatan (ubudiyah), terutama tentang perbedaan cara pandang atas agama yang mereka anut. Interpretasi yang berbeda dalam melihat suatu hukum agama dan diperparah dengan nalar egois yang kemudian meng-

\footnotetext{
5 Ali Syu'aibi, Meluruskan Radikalisme Islam (Ciputat: Pustaka Azhary, 2004), 137.

6 Endang Turmudzi, Riza Sihbudi (eds.), Islam dan Radikalisme di Indonesia (Jakarta: Lipi press, 2005), 242-243.
} 
hilangkan harmonisme dalam bermasyarakat. Seseorang yang dianggap tidak sesuai pemahamannya dianggap telah melenceng dari ajaran Islam yang sebenarnya. Kemudian, banyak orang yang berpengaruh menyeru kepada umat untuk kembali kepada ajaran agama yang benar. Ia menganggap bahwa ia berkewajiban untuk meluruskan ajaran agama yang bengkok dari akidah kehidupan. Sayangnya, ajaran yang benar ini hanya berdasar atas pemahamannya mereka sendiri. Baginya, ajaran sebagaimana dipahaminya sendirilah yang dianggap murni dan merupakan representasi dari ajaran Islam yang benar dan sah. Jika hal seperti ini terus berlanjut, maka tentunya perpecahan internal umat beragama tentunya akan terbuka lebar.

Bagi golongan radikalis, sikap tanpa kompromi (intoleran), tidak menghargai orang yang berbeda keyakinan, dan sikap keras merupakan "kebenaran" yang mereka pilih. Jalan kekerasan juga kadang dilakukan kaum ini. Mereka tidak sabar untuk memperbaiki keadaan dengan usaha pelan-pelan seperti pendidikan dan penyadaran. Mereka memilih jalan kekerasan dan tidak peduli akan akibat destruktif dari perbuatan yang mereka lakukan. Selain itu, mereka juga melakukan kekerasan atas nama agama, padahal ia sendiri bukan pemeluk agama yang baik.?

Melihat fenomena di atas, yang perlu kita refleksikan bersama, yaitu mengapa Islam yang merupakan agama rahmatan lil 'alamin, Islam yang merupakan agama samawi yang membawa misi syar'i mengayomi dan melindungi sesama umat manusia justru menjadi obyek dari semua aksi kerusuhan yang bernuansa radikal. Hal tersebut tiada lain dikarenakan ada sekelompok golongan yang dalam aktualisasi dakwahnya hanya mengedepankan kajian secara tekstualis, dan menggunakan berbagai aksi kekerasan yang berlabelkan Islam. Mereka menggunakan kedok 'jihad' sebagai legitimasi dari aksi yang mereka jalankan dan sebagai pembenaran tindakan-tindakan mereka tanpa mengabaikan harmonisasi dan kearifan lokal (local wisdom) seperti sediakala saat Islam masuk di Indonesia seperti yang telah dicontohkan oleh para Walisongo. Hal tersebut

7 Eko Prasetyo, et.al., Memahami Wajah Para Pembela Tuhan (Yogyakarta: Interfidie, 2003 ), 24. 
bukankah berbeda ketika kita berkaca pada kehidupan Rasul yang merupakan Nabi terakhir yang diutus Allah untuk menyampaikan wahyu kepada kita. Bukankah Rasul dalam penyampaian misi dakwahnya senantiasa melindungi dan mengayomi, bahkan mengharamkan darahnya kaum kafir dzimmi? Hal terebut semata-mata Islam adalah agama perdamaian dan pembawa keselamatan yang pada dasarnya tidak mengajarkan apalagi menganjurkan kekerasan dalam bentuk apapun. ${ }^{8}$ Terlepas dari itu semua, Horace M. Kallen mensinyalir, aksi radikalisasi agama yang seperti terjadi sekarang ini ditengarai oleh tiga kecenderungan. ${ }^{9}$

Pertama, radikalisasi agama merupakan respons terhadap kondisi yang sedang berlangsung. Biasanya respons tersebut muncul dalam bentuk evaluasi, penolakan atau bahkan perlawanan. Masalah yang ditolak bisa berupa ide, asumsi, lembaga, atau nilai-nilai yang dipandang bertanggung jawab terhadap kondisi yang ditolaknya. Kedua, radikalisasi agama tidak berhenti pada upaya penolakan, melainkan terus berupaya mengganti tatanan tersebut dalam suatu bentuk tatanan baru atau sebuah tatanan yang lain. Ciri ini menunjukkan bahwa di dalam radikalisasi agama terkandung suatu program atau pandangan dunia (world view) tersendiri. Kaum radikalis berupaya kuat untuk mengganti tatanan yang sudah ada dengan tatanan baru yang mereka inginkan (Islam kaffah). Ketiga, kuatnya keyakinan atau ideologi yang mereka bawa. Sikap ini pada saat yang sama dibarengi dengan penafian kebenaran dengan sistem lain yang akan diganti. Dalam gerakan sosial, keyakinan terhadap program atau filosofi sering dikombinasikan dengan cara-cara pencapaian yang mengatasnamakan nilai-nilai ideal seperti kemaslahatan umat atau kemanusiaan. Akan tetapi, kuatnya keyakinan ini dapat mengakibatkan munculnya sikap emosional yang menjurus pada aksi kekerasan. Dalam konteks inilah Ormas-Ormas Islam, seperti Front Pembela Islam (FPI), Majelis Mujahidin, Laskar Jihad Ahlussunnah Waljama’ah, Komite Indo-

8 Alwi Shihab, Membedah Islam di Barat: Menepis Tudingan Meluruskan Kesalahpahaman (Yogyakarta: Andi Offset, 2004), 2-4.

9 Zada Khamami, Islam Radikal: Pergulatan Ormas-Ormas Islam Garis Keras di Indonesia (Jakarta: Teraju, 2002), 16-17. 
nesia untuk Solidaritas Dunia Islam (KISDI), memiliki ciri-ciri yang sebagaimana diungkapkan oleh Horace M. Kallen di atas. Pertama, mereka memperjuangkan Islam secara kaffah (totalistik); syariat Islam sebagai hukum Negara, Islam sebagai dasar Negara, sekaligus Islam sebagai sistem politik sehingga bukan demokrasi yang menjadi suara aspirasi rakyat yang menjadi sistem politik. Kedua, mereka mendasarkan praktik keagamaanya pada orientasi masa lalu (salafi). Ketiga, mereka sangat memusuhi Barat dengan segala produk peradabannya, seperti sekularisasi dan modernisasi. Keempat, perlawanan dengan gerakan liberalisme Islam yang tengah berkembang di kalangan Muslim Indonesia. ${ }^{10}$ Oleh sebab itu, Ormas-Ormas Islam seperti ini bisa dikategorikan ke dalam golongan Islam radikal.

Menganalisa hal-hal tersebut di atas, setidaknya kemunculan Islam radikal (radikalisme agama) di Indonesia ditengarai oleh dua faktor. Pertama, faktor internal dari dalam umat Islam sendiri. Faktor ini terjadi karena adanya penyimpangan norma-norma agama. Kehidupan sekuler dalam kehidupan masyarakat mendorong mereka kembali pada otentitas (fundamen) Islam. Sikap ini ditopang dengan pemahaman agama yang totalistik (kaffah) dan formalistik yang bersikap kaku dalam memahami teks-teks agama. Kajian terhadap agama hanya dipandang dari satu arah, yaitu tekstual, tidak melihat dari faktor lain, sehingga tindakan-tindakan yang mereka lakukan harus merujuk pada perilaku Nabi secara literal. Kedua, faktor eksternal di luar umat Islam, baik yang dilakukan oleh rezim penguasa atau hegemoni dari Barat yang tidak mendukung terhadap penerapan syariat Islam dalam sendi-sendi kehidupan. ${ }^{11}$

Sesungguhnya strategi penanganan dan perlawanan terhadap tindakan yang bernuansa radikal, baik itu yang bersifat umum atau telah menjurus kepada radikalisme agama yang menimbulkan kerusakan dan menebarkan kekerasan di mana-mana sejatinya telah gencar dilakukan. Hal tersebut dilakukan baik secara langsung, yaitu dengan menggunakan kekuatan (hard power approach), seperti yang dilakukan oleh Densus 88

\footnotetext{
${ }^{10}$ Ibid., 17.

${ }^{11}$ Ibid., 95.
} 
maupun dengan cara pendekatan bimbingan (soft approach), seperti yang dioperasikan oleh Badan Nasional Penanggulangan Terorisme (BNPT). Penanganan tindak radikal tersebut, tampak sekali terlihat setelah munculnya berbagai peristiwa kerusuhan yang bernuansa agama. Pada level tertentu bom pun menjadi isu yang santer dibicarakan dan menjadi sorotan dunia Internasional, terutama yaitu pasca ledakan bom Bali 12 Oktober 2002. Kajian atas peran-peran jaringan Islam Radikal menjadi obyek studi-studi di berbagai forum.

Berbagai aksi kekerasan yang berkedok agama semakin marak di Indonesia. Hal tersebut ditengarai sebagai aksi dari para pemikir kelompok radikal yang ada di Indonesia. Beberapa kelompok Islam tersebut adalah mereka yang tergabung mulai dari Kelompok Salafi, Negara Islam Indonesia (NII), Hizbut Tahrir Indonesia (HTI), Majelis Mujhidin Indonesia (MMI), dan Front Pemuda Islam Surakarta (FPIS), sampai dalam lembaga pendidikan seperti Pondok Pesantren al-Mukmin Ngruki, Solo. ${ }^{12}$

Masuknya Pesantren al-Mukmin Ngruki dalam daftar "terorisme" karena orang yang paling dicurigai terlibat dalam kasus terorisme di Asia Tenggara, yaitu Ustaz Abu Bakar Ba’asyir adalah pendiri dan pengasuh pesantren tersebut. Di sisi lain, bahkan keyakinan banyak pihak semakin menguat ketika peristiwa bom Bali pada 1 Oktober 2002 dan teror lainnya seperti pada 17 Juli 2009, bom kembali diledakkan di Mega Kuningan Jakarta yang sebagian pelakunya memiliki keterkaitan dengan Ngruki atau setidak-tidaknya dekat dengan Abu Bakar Baasyir. ${ }^{13}$

Lebih spesifik lagi, bila kita amati aksi radikalisme agama yang terjadi di Jawa Tengah, khususnya di wilayah Semarang, dapat kita lihat seperti masuknya jaringan NII (Negara Islam Indonesia). Dalam kasus tersebut yaitu tepatnya pada 22 Juli 2011 saja terdapat enam tersangka dengan dakwaan tindakan makar. Keenam tersangka tersebut adalah Totok Dwi Harjanto alias Nizam Sidik, warga Banyumanik Semarang;

\footnotetext{
12 Turmudi, Islam dan Radikalisme, 120.

${ }^{13}$ Abdurrahman, Pribadi Abu, Rayyan. Membongkar Jaringan Terorisme (Jakarta: Abdika Press, 2009), 53.
} 
Sulamin, warga Kebumen; Mardiyanto, warga Ungaran Barat, Kabupaten Semarang; Nur Basuki, warga Magelang; Supandi, warga Jakarta Selatan; dan Mujono Agus Salim, warga Tegal. ${ }^{14}$

Dakwah yang merupakan manifestasi dari nilai-nilai agama yang ditransfer ke dalam jiwa dan raga manusia di dalam praktiknya dapat diaplikasikan melalui dua bentuk pendekatan, yaitu dakwah secara kultural dan struktural. ${ }^{15}$ Dakwah dengan pendekatan kultural merupakan suatu konsep pendekatan dakwah dengan cara menyentuh akar budaya yang ada, menyampaikan ajaran Islam dengan tetap menghormati dan menghargai tradisi terdahulu yang sudah lama tertanam seperti yang telah dicontohkan oleh Walisongo dalam penyebaran dakwahnya. ${ }^{16}$ Tampaknya hal demikianlah yang diterapkan oleh NU. NU yang selalu mengedepankan ajaran tasammuh (toleran), tawassut (moderat) yang dalam pengambilan hukumnya tidak hanya secara tektual, tetapi mengambil juga hukum dari al-Qu'ran, Hadis, ijma' dan qiyas adalah merupakan fenomena yang mengundang toleransi keberagamaan yang ada di Indonesia. ${ }^{17}$ Penafsiran al-Qur'an secara kaidah yang benar dengan memperdulikan sabab nuzul-nya ayat, maka transformasi pesan agama tidak serta merta diterapkan ke dalam kehidupan secara membabi buta. Akan tetapi, tetap memperhatikan kearifan lokal (local wisdom) yang ada, yang mana hal tersebut tidak bisa terlepas dari sejarah lahirnya NU itu sendiri. NU mengambil tindakan dengan cara bagaimana menyampaikan pesan Islam yang sesuai dengan kondisi sosio-kultural budaya Indonesia. NU bersikap sebagai Islam yang moderat, sebagai Muslim yang toleran, dalam kehidupan yang pluralis yang tentunya tidak bertentangan dengan ideologi negara, yaitu Pancasila. ${ }^{18}$

${ }^{14}$ http://wartapedia.com/nasional/hukum-dan-kriminal/4334radikalisme-10-jaksasiapkansusunan-dakwaan-tersangka-nii.html. Diakses pada tanggal 23 Januari 2018.

${ }^{15}$ Muhammad Sulthon, Desain Ilmu Dakwah (Yogyakarta: Pustaka Pelajar, 2003), 117.

${ }^{16}$ Sulthon, Desain Ilmu Dakwah, 27.

${ }^{17}$ Laode Ida, Kaum Progresif dan Sekularis Baru (Jakarta: Penerbit Erlangga, 2004), 7.

${ }^{18}$ Baso Ahmad, NU Studies: Pergolakan Pemikiran Antara Fundamentalisme Islam dan Fundamentalisme Neo-Liberal (Jakarta: Penerbit Erlangga, 2006), 5. 
Di sisi lain, dakwah struktural adalah gerakan dakwah yang berada dalam kekuasaan. Dalam dakwah struktural bergerak mendakwahkan ajaran Islam melalui struktur sosial, politik maupun ekonomi. Yang dalam hal ini NU yang merupakan ormas dengan basis massa terbesar yang tersebar di seluruh wilayah nusantara, tentunya mempunyai visi, misi, dan arahan bagi semua anggota dan lembaga yang berada di bawah naunganya. Hal tersebut dilakukan sebagai wujud tanggung jawab dan apresiasi NU terhadap keutuhan wilayah negara dari disintegrasi, baik dari luar maupun dalam negeri yang berupa penyebaran ideologi yang berupaya memecah belah keutuhan Negara. Mengingat NU merupakan salah satu lembaga yang mempunyai kiprah besar dalam perjuangan Negara Indonesia ini, NU turut pula dalam menentukan ideologi negara yaitu Pancasila sebagai dasar negara. ${ }^{19}$

Maraknya tindak radikalisme agama yang berimplikasi pada kekerasan, sedikit banyak telah mempengaruhi pandangan masyarakat umum tentang Islam. Hal tersebut terlebih lagi ketika media cetak dan elektronik banyak memberitakan masalah-masalah baru yang terjadi berkaitan dengan hal tersebut. Seperti disebutkan di atas, kemunculan Islam radikal di Indonesia yang ditengarai oleh faktor internal yaitu adanya penyimpangan norma-norma agama, dan juga faktor eksternal seperti yang dilakukan oleh rezim penguasa atau hegemoni dari Barat mendorong NU sebagai Ormas dakwah untuk turut serta dalam penanganan masalah tersebut.

\section{Konsep Dasar Strategi Dakwah}

Strategi pada mulanya merupakan suatu istilah yang diadopsi dari kalangan militer, yang merujuk pada penggunaan dan pemanfaatan dana, daya, dan peralatan yang tersedia untuk memenangkan pertempuran. Akan tetapi dewasa ini sesuai dengan perkembangan kehidupan pada abad modern, istilah tersebut ternyata tidak hanya digunakan dalam istilah militer saja, akan tetapi juga digunakan oleh berbagai organisasi

\footnotetext{
${ }^{19}$ Baso, NU Studies, 56.
} 
non militer tak terkecuali di dalamnya yaitu organisasi masyarakat seperti Nahdlatul Ulama (NU) di dalam pengembangan dakwahnya. Hal tersebut tiada lain dikarenakan dakwah merupakan suatu aktivitas untuk mengajak manusia menuju suatu tujuan, ${ }^{20}$ yang dalam hal ini tujuan tersebut tiada lain yaitu menuju ke jalan Allah. Esensi tersebut tertuang dalam firman Allah dalam Surat an-Nahl ([16]: 125) sebagai berikut:

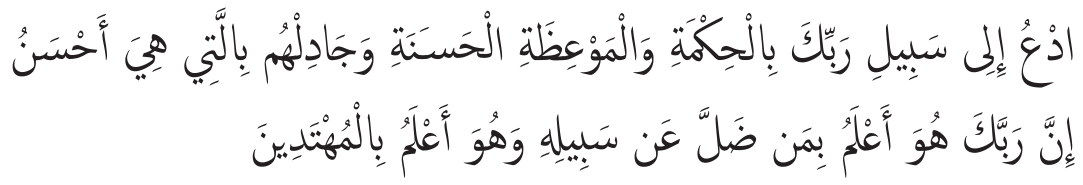

Serulah (manusia) kepada jalan Tuhan-mu dengan hikmah dan pelajaran yang baik dan bantahlah mereka dengan cara yang baik. Sesungguhnya Tuhanmu Dialah yang lebih mengetahui tentang siapa yang tersesat dari jalan-Nya dan Dialah yang lebih mengetahui orang-orang yang mendapat petunjuk.

Dari ayat di atas, kita dapat mengetahui bahwa di dalamnya juga memuat metodologi atau cara-cara yang harus kita terapkan dalam melaksanakan suatu aktivitas dakwah, yang tentunya harus disesuaikan dengan kemajuan dan perkembangan zaman (sholih fi kulli zaman wa al-makan). Dengan kata lain, konsepsi tentang dakwah atau menyeru ke jalan Allah seperti yang tersebut dalam ayat di atas mengindikasikan, bahwa kewajiban dakwah harus mempertimbangkan berbagai cara ataupun strategi yang ditempuh dengan tanpa mengabaikan kondisi mad'u (objek dakwah). ${ }^{21}$

${ }^{20}$ Tujuan tersebut yang kemudian digarisbawahi oleh M. Ridlo Syabibi, agar apa yang menjadi tujuan dari aktivitas dakwah dapat diterima secara efektif dan efisien mutlak diperlukan kiat-kiat dan strategi khusus. Hal inilah yang oleh Syabibi dinamakan sebagai strategi dakwah. M. Ridlo Syabibi, Metodologi Ilmu Dakwah: Kajian Ontologis Dakwah Ikhwan al-Safa (Yogyakarta: Pustaka Pelajar, 2008), 135.

${ }^{21}$ Kewajiban melaksanakan dakwah dengan pola-pola, seperti hikmah, mau'idzoh hasanah dan mujadalah, disebut dengan pola-pola dakwah yang mempertimbangkan keadaan objek dakwah yang oleh Ahmad Anas disebut dengan pendekatan dakwah yang mengacu pada human relation. Ahmad Anas, Paradigma Dakwah Kontemporer: Aplikasi Teoritis dan Praktis Dakwah Sebagai Solusi Problematika Kekinian (Semarang: 
Seiring dengan berkembangnya dunia sekarang ini dengan segala dinamika yang ada, setiap organisasi yang berorientasi pada pengembangan dakwah Islam dituntut untuk dapat merumuskan suatu strategi dan penerapannya. Di sisi lain juga dituntut untuk mampu berbenah diri dalam menyiasati dakwahnya agar apa yang menjadi pesan syar'i dapat diterima oleh mad'u (objek dakwah). Tak terkecuali dalam organisasi yang profit (nirlaba), organisasi dakwah pun jika menginginkan dapat tetap eksis dan survive, maka ia harus mampu menentukan setiap arah kebijakan dan menerapkan strategi yang tepat untuk menjalankan visi dan misinya, serta untuk mengantisipasi segala kemungkinan yang ada, agar apa yang menjadi cita-cita dan tujuan organisasi dapat tercapai.

Melihat deskripsi dari beberapa fenomena di atas, tentu kita menyadari bahwa peran strategi bagi aktivitas dakwah sangat penting dalam menentukan sebuah langkah kebijakan suatu organisasi. Lebih lanjut, memahami arti dari sebuah kata "strategi" memanglah tidak mudah. Hal tersebut karena setiap literatur yang didapat antara satu dengan yang lain seringkali memberikan definisi yang berbeda, bahkan bisa dikatakan sampai saat ini tidak ada definisi yang baku mengenai istilah tersebut. Hal tersebut mengandung arti bahwa istilah strategi mempunyai ruang lingkup yang sangat luas dan tidak terbatas, sesuai dengan setiap kata yang merangkainya seperti pada istilah strategi dakwah.

Perlu kita pahami bersama, bahwasanya istilah strategi dakwah merupakan kombinasi dari dua disiplin ilmu yang berbeda. Akan tetapi, secara konseptual-skematis, dalam penelitian ini akan dijelaskan pengertian tersebut satu per satu, kemudian setelah ditemukan kejelasan masing-masing barulah akan ditarik suatu kesimpulan dan didefinisikan. Pada dasarnya istilah kata strategi yaitu berasal dari kata strategos (bahasa Yunani) yang berarti jenderal. Penggunaan istilah tersebut pertama kali dipopulerkan oleh kalangan militer. Dalam kamus induk disebutkan, strategi ialah kiat atau cara-cara yang baik dan menguntungkan dalam setiap tindakan. ${ }^{22}$ Penggunaan istilah strategi di kalangan militer biasanya

Pustaka Rizki Putra, 2006), 116.

${ }^{22}$ M. Dahlan, Lya Sofwan, Kamus Induk Istilah Ilmiah (Surabaya: Target Press, 
lebih didominasi dalam situasi peperangan, sebagai tugas komandan dalam menghadapi musuh, yang bertanggung jawab mengatur cara atau taktik untuk memenangkan peperangan.

Dalam pengertian di atas, strategi juga dapat dipahami sebagai suatu seni para jenderal dalam menjalankan taktiknya di Medan pertempuran. Dari sudut etimologis, strategi sebuah organisasi dapat diartikan yaitu sebagai suatu kiat, cara dan taktik yang dirancang secara sistematis dan terarah dalam melaksanakan fungsi-fungsi organisasi. ${ }^{23}$ Starategi juga dipahami sebagai segala cara dan daya untuk menghadapi sasaran tertentu dalam kondisi tertentu agar memperoleh hasil yang diharapkan secara maksimal. Jika kita merujuk kepada al-Qur'an, sebenarnya juga terdapat ayat-ayat yang mengindikasikan tentang strategi. Di antara ayat yang menerangkan hal tersebut yaitu seperti yang terdapat dalam Surat an-Nisa' ([4]: 71).

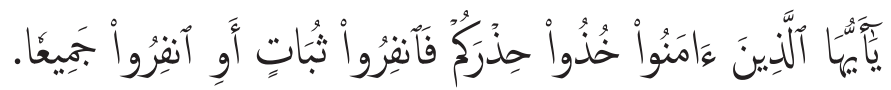

Hai orang-orang yang beriman, bersiap siagalah kamu, dan majulah (ke medan pertempuran) berkelompok-kelompok, atau majulah bersama-sama.

Wahbah Az-Zuhaili dalam Tafsir Munir memaknai lafadz khudzuu khidzrokum dengan lafaz ikhtarizuu wa tayaqqodzu, maksudnya yaitu berhati-hati dan bangun untuk melawan musuh. Sedangkan dalam lafaz fan firuu diartikan dengan inhadzuu ila qitalihi yang bermakna bangkit memerangi musuh. ${ }^{24}$ Maka, sesuai ayat di atas, strategi dapat bermakna kehati-hatian, sikap siaga dan waspada terhadap musuh, serta berusaha bangkit untuk menyerangnya. Dalam suatu organisasi, sebelum menen-

2003), 740.

${ }^{23}$ Hadari Nawawi, Manajemen Strategik: Organisasi Non Profit Bidang Pemerintahan dengan Ilustrasi di Bidang Pendidikan (Yogyakarta: Gadjahmada University Press, 2005), 147.

${ }^{24}$ Wahbah Az-Zuhaili, Al-Tafsiiru al-Muniiru: Fi al-Aqiidah, wa asy-Syariah wa sl-Manhaj (Beirut: Darul Fikri, 1991), 150. 
tukan kebijakan-kebijakan pastilah dituntut untuk bersikap hati-hati dan waspada dalam menyusun suatu kebijakan. Hal tersebut dimaksudkan agar kinerja suatu organisasi dapat terkontrol dan terarah sesuai dengan haluan kebijakan yang telah ditetapkan. Menurut M. Quraisy Shihab dalam Tafsir al-Misbah, ayat di atas mengandung makna kehatihatian, dan menghadapi musuh dengan upaya mengetahui kekuatan dan kelemahan mereka, serta cara-cara yang paling tepat untuk menangkis dan melumpuhkan mereka. Ayat al-Qur'an di atas juga menjelaskan bagaimana kita dituntut untuk dapat mengelola dan mengatur pertempuran agar kita bisa meraih suatu kemenangan. ${ }^{25}$

Konsepsi tentang strategi ternyata dewasa ini tidak hanya dipergunakan oleh kalangan militer, akan tetapi oleh berbagai organisasi non militer. Dalam hal ini strategi bersinggungan dengan masalah-masalah yang berkaitan dengan efektivitas dan efisiensi. Dengan demikian, strategi dalam sebuah organisasi haruslah memanfaatkan kemampuan organisasi sedemikian rupa, dengan memperhitungkan kesempatan dan risiko yang timbul, sehingga pemanfaatan kemampuan organisasi tersebut mendatangkan efektivitas dan efisiensi yang akan dacapai dalam waktu tertentu. Ciri-ciri yang tercipta dengan pemanfaatan dana, daya, dan tenaga yang sesuai dengan perubahan lingkunganlah yang dimaksud dengan srategi. ${ }^{26}$

Strategi seperti yang dikemukakan oleh para ahli. Pertama, menurut Karl Van Calusewitz. Menurutnya strategi diartikan sebagai suatu seni bagi tentara dalam sebuah pertempuran. Kedua, menurut Drucer, strategi adalah mengerjakan sesuatu yang benar (doing the right things). ${ }^{27}$ Dari kedua pengertian di atas, dapat dipahami bahwa strategi tidaklah sebatas dalam cakupan wilayah teori saja, akan tetapi strategi juga ter-

\footnotetext{
${ }^{25}$ M. Quraisy Shihab, Tafsir al-Misbah: Pesan, Kesan, dan Keserasian al-Quran (Jakarta: Lentera Hati, 2002), 503.

${ }^{26}$ Sondang P. Siagian, Analisis serta Perumusan Kebijaksanaan dan Struktur Organisasi (Jakarta: CV. Haji Masagung, 1994), 16-17.

${ }^{27}$ Sri Wahyudi, Manajemen Strategik: Pengantar Berpikir Strategik (Jakarta: Binarupa Aksara, 1996), 16.
} 
masuk dalam segi aplikasi dan implementasi. Dari pemaparan di atas, dapat diambil beberapa pengertian tentang strategi, yaitu strategi dapat diartikan sebagai kerangka atau rencana yang mengintegrasikan tujuantujuan (goals), kebijakan-kebijakan (policies) dan tindakan atau program organisasi. Strategi adalah suatu cara bagaimana suatu organisasi dapat mencapai suatu tujuan yang diinginkan pada masa yang akan datang. Strategi adalah pola tindakan dan alokasi sumber daya yang dirancang untuk mencapai tujuan organisasi. ${ }^{28}$

\section{Faktor-iaktor yang Mempengaruhi Penyusunan Strategi Dakwah}

Dakwah secara etimologi berasal dari bahasa Arab. ${ }^{29}$ Kata tersebut secara leksikal memiliki arti seruan, panggilan dan ajakan. Adapun terminologi dakwah seperti diungkapkan oleh para ahli, sebagai berikut dalam kitabnya, Hidayatul Mursyidin, Syekh Ali Mahfud mengungkapkan bahwa dakwah adalah mengajak manusia untuk mengerjakan kebaikan dan mengikuti petunjuk ( $a l-h u d a)$, menyuruh mereka berbauat baik dan melarang mereka dari perbutan yang jelek agar mereka mendapat kebahagiaan dunia dan akhirat. Menurut Ibnu Taimiyah, dakwah adalah mengajak seseorang agar beriman kepada Allah dan apa yang dibawa oleh para Rasul dengan membenarkan apa yang mereka beritakan dan mengikuti apa yang mereka perintahkan.

Abu Bakar Aceh mengungkapkan, "Dakwah adalah perintah meng-adakan seruan kepada semua manusia untuk kembali dan hidup sepanjang ajaran Allah yang benar, dilakukan dengan penuh kebijaksanaan dan nasehat yang baik." Sedangkan menurut Thoha Yahya Omar, dakwah ialah mengajak manusia dengan cara bijaksana kepada jalan yang benar sesuai dengan perintah Tuhan untuk kemaslahatan dan kebahagiaan di dunia dan di akhirat. Abdul Karim Zaidan melihat dakwah merupakan panggilan ke jalan Allah.

\footnotetext{
28 Tripomo, Manajemen Strategi (Bandung: Rekayasa Sains, 2005), 17.

${ }^{29}$ M. Munir, Wahyu Ilaihi, Manajemen Dakwah (Jakarta: Kencana, 2006), 36.
} 
Dari beberapa pengertian di atas, dapat kita pahami bahwasanya eksistensi dakwah pada intinya merupakan ajakan atau panggilan yang diarahkan pada masyarakat luas untuk menerima kebaikan dan meninggalkan keburukan sesuai dengan koridor syara'. Selain itu, dakwah juga merupakan suatu usaha untuk menciptakan situasi yang lebih baik sesuai dengan ajaran-ajaran Islam dalam setiap lini kehidupan.

Dari penjelasan di atas, strategi dakwah dapat diartikan sebagai suatu proses dalam mengatur, mengarahkan, dan menentukan cara, daya, dan upaya untuk menghadapi sasaran dakwah dalam situasi dan kondisi tertentu agar apa yang menjadi tujuan dan sasaran dakwah dapat tercapai secara maksimal. Dengan kata lain, strategi dakwah merupakan siasat, taktik, atau cara yang dirancang secara sistematik dan terarah yang ditempuh dalam rangka mencapai tujuan dakwah. Hal demikian tentunya mengindikasikan bahwa keberadaan dari apa yang dinamakan sebagai "strategi dakwah" adalah mempunyai peran yang sangat penting dalam suatu organisasi dakwah.

Keberhasilan suatu organisasi dalam mencapai tujuan dan berbagai sasarannya akan cenderung ditentukan oleh dinamika organisasi yang bersangkutan. Dinamika yang tercipta dalam sebuah organisasi tersebut sejatinya disebabkan oleh adanya interaksi yang terjadi baik antara organisasi dengan lingkunganya, maupun satuan-satuan kerja dalam organisasi tersebut. Pada giliranya interaksi yang terjadi merupakan suatu akibat dan bukan merupakan tuntutan dari interdependensi yang terdapat antara organisasi dengan lingkunganya dan antara berbagai subsistem dalam organisasi.

Dinamika yang mutlak terjadi dalam organisasi dakwah, mendorongnya untuk meningkatkan kemampuan dalam perumusan strategi yang diterapkan. Pada titik tertentu dinamika itulah yang akan mempengaruhi dalam proses penyusunan strategi dakwah. Hal ini penting diketahui dan dipahami oleh suatu organisasi, dikarenakan dinamika perkembangan zaman yang terus berubah pada setiap lini kehidupan telah mendorong perubahan pula dalam penetapan strategi. Bila kita cermati terdapat beberapa faktor yang turut berpengaruh dalam penyu- 
sunan strategi dakwah. Di antara faktor-faktor yang turut andil dalam mempengaruhi penentuan strategi adalah faktor lingkungan, baik itu yang berasal dari dalam organisasi itu sendiri (internal factor) ataupun faktor lain yang berasal dari lingkungan luar organisasi (eksternal factor). Dalam bukunya Siagian mensinyalir setidaknya terdapat empat faktor dalam menentukan strategi, yaitu: ${ }^{30}$

1. Faktor Ekonomi. Tidak hanya dalam organisasi profit, organisasi non-profit pun termasuk di dalamnya organisasi dakwah, di dalam menentukan dan menerapkan strateginya pastilah bergantung pada sumber daya manusia (SDM) dan sumber daya alam (SDA) yang ia miliki. Hal tersebut dikarenakan programprogram yang telah tersusun dalam suatu organisasi pastilah tidak akan bisa berjalan tanpa adanya SDM dan SDA yang mendukungnya. Dalam hal ini ekonomi menjadi faktor utama yang berpengaruh dalam penerapan strategi suatu organisasi. Hal tersebut dikarenakan suatu organisasi dalam menentukan langkahnya pastilah akan berorientasi pada sumber daya yang ada baik itu sumber daya yang bersifat material atau immaterial. Meskipun target yang akan dicapai tinggi akan tetapi tanpa ada dukungan dari sisi materi maka dapat dipastikan target tersebut akan sulit terrealisasi.

2. Faktor Politik. Politik yang sedang hangat terjadi baik dalam lingkungan internal organisasi ataupun di luar organisasi turut pula berpengaruh pada strategi yang diterapkan dalam suatu organisasi. Politik yang mempengaruhi penetapan strategi dalam suatu organisasi ketika tidak disikapi dengan kemaslahatan bersama dalam pencapaian tujuan organisasi dapat membawa dampak buruk terhadap organisasi yang bersangkutan. Organisasi bisa jadi hanya dimanfaatkan oleh segelintir orang yang tidak bertanggung jawab demi mencapai tujuan pribadinya. Sebagai suatu contoh gap yang terjadi antara personal anggota dalam suatu organisasi karena perbedaan politik, maka sudah

\footnotetext{
${ }^{30}$ Siagian, Analisis serta Perumusan Kebijaksanaan, 107-108.
} 
pasti strategi yang telah dicanangkan kurang bisa terlaksana seperti apa yang menjadi tujuan organisasi tersebut.

3. Faktor dari Implikasi Kebijakan Pemerintah. Kebijakan-kebijakan pemerintah yang berlaku dalam suatu negara tentunya berimbas pula pada semua lini kehidupan tak terkecuali dalam organisasi dakwah. Hal demikian karena peraturan yang ditetapkan oleh suatu pemerintah wajib dilaksanakan oleh semua lapisan masyarakat, dan hal inilah yang turut pula mewarnai dalam strategi dakwah yang diterapkan dalam suatu organisasi.

4. Faktor Teknologi. Tekhnologi sebagai suatu sarana yang dimiliki oleh sebuah organisasi, tentunya akan mendukung penetapan strategi yang lebih baik dibandingkan dengan organisasi yang masih menggunakan data manual. Begitu pula terlaku dalam suatu organisasi yang masih menggunakan peralatan yang seadanya, tentunya target dari strategi yang dihasilkan akan bergantung dari sarana dan prasarana yang mendukungnya. Organisasi dakwah yang telah memiliki seperangkat teknologi yang telah maju, memungkinkan menerapkan strategi dakwah dengan teknologi yang telah ada.

Dari faktor-faktor yang tersebut di atas, tentunya kita mengetahui bahwa strategi dakwah yang diterapkan dalam suatu organisasi dakwah adalah sangat dipengaruhi dari faktor lingkungannya, baik itu lingkungan dalam ataupun lingkungan luar organisasi.

\section{Tekhnik dan Proses dalam Penyusunan Strategi Dakwah}

Agar strategi yang diterapkan oleh sebuah organisasi dapat berhasil maksimal dan tidak terjadi ketimpangan kebijakan, maka antara rencana strategis (Renstra) dan rencana operasional (Renop) haruslah berjalan sejajar guna mewujudkan visi dan misi dari strategi yang ditargetkan tersebut. Untuk mewujudkan hal tersebut, tentunya dibutuhkan teknikteknik dalam penetapan strategi yang dimaksud. Dalam bukunya, Hadari 
Nawawi menyebutkan teknik-teknik yang bisa digunakan antara lain: ${ }^{31}$

1. Teknik Matrik Faktor Internal dan Eksternal (the internal and eksternal factor matrix), yaitu penyusunan strategi dengan cara menganalisa dan mengevaluasi untuk mengetahui kelemahan dan kekuatan, serta mengkaji peluang dan hambatan yang dihadapi dalam melaksanakan suatu misi, baik yang bersumber dari dalam ataupun dari luar organisasi.

2. Teknik Matrik Memperkuat dan Mengevaluasi Posisi (the strengh position and evaluation matrix), yaitu penyusunan strategi dengan cara mencocokkan sumber daya internal yang dimiliki (kinerja organisasi) untuk memperkuat posisi dengan peluang yang ada dan mengatasi atau menghindari risiko eksternal.

3. Teknik Matrik dari Kelompok Konsultas Boston (the boston consulting group matrik), yaitu penyusunan strategi dengan cara menetapkan strategi yang berbeda-beda untuk setiap biro atau departemen sebagai satu unit kesatuan.

Dalam penyusunan suatu strategi dakwah, selain memerlukan suatu teknik penyusunan strategi seperti yang tersebut di atas, di sisi lain juga harus mempertimbangkan tahapan-tahapan penyusunannya. Tahapantahapan dalam penyusunan strategi dakwah dimaksudkan agar lebih mudah dalam melakukan manajemen atas strategi dakwah yang akan diterapkan. Adapun tahapan-tahapan dalam penyusunan strategi seperti yang dikemukakan oleh Triton PB dapat dikelompokkan ke dalam enam tahapan penyusunan strategi. Adapun tahapan-tahapan tersebut adalah sebagai berikut:

1. Seleksi yang mendasar dan kritis terhadap permasalahan.

2. Menetapkan tujuan dasar dan sasaran strategi.

3. Menyusun perencanaan tindakan (action plan).

4. Menyusun rencana penyumberdayaan.

5. Mempertimbangkan keunggulan.

\footnotetext{
${ }^{31}$ Nawawi, Manajemen Strategik, 174-177.
} 
6. Mempertimbangkan keberlanjutan. ${ }^{32}$

Selanjutnya keenam langkah tersebut dapat dijabarkan sebagai berikut. Pertama, seleksi mendasar dan kritis terhadap permasalahan. Seleksi tersebut biasanya dilakukan berdasarkan faktor internal ataupun eksternal yang menjadi penyebab permasalahan dalam suatu organisasi dakwah. Adapun seleksi tersebut dapat dilakukan dengan langkahlangkah berikut ini:

1. Mengidentifikasi dan menginventarisasi seluruh permasalahan.

2. Mengidentifikasi dan mengelompokkan masing-masing permasalahan berdasarkan faktor internal dan eksternalnya.

3. Mengurutkan permasalahan berdasarkan tingkat kepentinganya.

4. Menentukan skala prioritas penyelesaian masalah.

Kedua, menetapkan tujuan dasar dan sasaran strategi. Tujuan dasar dan sasaran yang hendak dicapai oleh suatu organisasi hendaknya tidak bertentangan dengan arah, cakupan, dan perspektif jangka panjang suatu organisasi, karena tujuan dan sasaran merupakan acuan yang menjadi dasar pengukiran berhasilnya strategi yang diterapkan.

Ketiga, action plan. Dalam penyusunan strategi, biasanya terdapat dua tipe yang harus diperhatikan, yaitu rencana konsepsional (teoretis) dan dan rencana tindakan. Suatu rencana mungkin baik secara koseptual akan tetapi belum tentu sesuai atau baik di lapangan. Hal inilah yang kemudian sebuah strategi akan ditentukan oleh penyusunan rencana tindakan. Oleh karena itu, dalam penyusunan suatu strategi setidaknya harus memperhatikan langkah-langkah sebagai berikut: pertama, meninjau kembali langkah-langkah dalam strategi yang akan mungkin diterapkan; dan kedua, mengidentifikasi dan menginventarisasi faktor-faktor operasional, baik yang bersumber dari lingkungan internal ataupun eksternal.

${ }^{32}$ Triton PB, Marketing Strategis: Meningkatkan Pangsa Pasar dan Daya Saing (Yogyakarta: Tugu Publiser, 208), 17. 
Selain itu, John M. Bryson juga mengemukakan bahwa untuk mencapai strategi yang tepat, suatu organisasi dituntut untuk memperhatikan langkah-langkah yang tepat pula di dalam menyusunannya. Adapun langkah-langkah yang diungkapnnya adalah sebagai berikut: ${ }^{33}$

Pertama, yaitu memprakarsai dan menyepakati suatu proses perencanaan strategis. Hal ini dilakukan sebagai upaya untuk menegosiasikan suatu kesepakatan dengan orang-orang penting pembuat keputusan (decision maker) atau pembentuk opini (opini leaders) internal dan tidak mungkin menutup kemungkinan dari kalangan eksternal tentang seluruh upaya perencanaan strategi dan langkah perencanaan yang penting yang akan diterapkan. Dengan kata lain, dalam suatu organisasi harus terdapat beberapa orang atau kelompok yang memulai suatu proses didalam penetapan suatu strategi, yang mana dalam suatu organisasi harus terdapat salah satu pemrakarsa yang menetapkan secara tepat siapa saja yang tergolong orang-orang penting pembuat keputusan. Ketika hal ini sudah bisa dilakukan, maka langkah selanjutnya adalah menetapkan orang, kelompok, atau suatu unit organisasi yang harus dilibatkan dalam upaya perencanaan suatu strategi. Kesepakatan awal yang dihasilkan kemudian akan dinegosiasikan dengan setidak-tidaknya beberapa dari pembuat keputusan dalam organisasi tersebut.

Kedua, yaitu memperjelas mandat organisasi. Tidak dapat dipungkiri, bahwa mandat yang terdapat dalam suatu organisasi memiliki kedudukan yang sangat krusial di dalam dinamika roda suatu organisasi. Mandat yang bersifat formal ataupun informal yang ditempatkan pada suatu organisasi adalah merupakan suatu "keharusan" yang dihadapi oleh suatu organisasi yang bersangkutan. Dengan memperjelas mandat suatu organisasi, maka suatu organisasi dalam oprasionalnya dapat mengetahui fungsi dan tugas, serta tujuan organisasi tersebut.

\footnotetext{
${ }^{33}$ M. Miftahuddin, Perencanaan Strategis Sebagai Organisasi Sosial (Strategic Planning for Public and Nonprofit Organizations: A Guide Strengthering and Sustaining Organizational Achievement), terj. Jhon M Bryson. Cet. IV (Yogyakarta: Pustaka Pelajar, 2001), 55-57.
} 
Ketiga, yaitu mempertegas dan memperjelas misi dan nilai-nilai yang diusung oleh suatu organisasi. Misi suatu organisasi yang dimaksud di sini adalah misi yang berkaitan erat dengan mandatnya. Melihat sudut pandang tersebut, maka kehadiran suatu organisasi dapat dipahami sebagai suatu alat menuju akhir pencapaian tujuan, akan tetapi bukan akhir dari tujuan itu sendiri. Memperjelas misi haruslah disusun lebih dari sekadar memperjelas keberadaan organisasi.

Keempat, yaitu menilai lingkungan eksternal. Di sini tim perencanaan harus mengeksplorasi lingkungan di luar organisasi untuk mengidentifikasi peluang dan ancaman yang akan dihadapi oleh organisasi ke depannya.

Kelima, yaitu menilai lingkungan internal. Untuk mengenali kekuasaan dan kelemahan internal, organisasi dapat memantau sumber daya (input), strategi kerja (proses), dan kinerja (output). Karena sebagian besar organisasi biasanya mempunyai banyak informasi tentang input organisasi, seperti gaji, pasokan, bangunan fisik, dan personalia yang sama dengan personalia purna waktu (full-time equivalent).

Keenam, yaitu mengidentifikasi isu strategis yang dihadapi organisasi. Identifikasi terhadap isu-isu strategis akan dapat berjalan maksimal apabila kelima langkah sebelumnya sudah bisa dilakukan dengan baik. Perencanaan strategis memfokuskan kepada tercapainya sasaran yang terbaik antara organisasi dan lingkungannya. Oleh karena itu, perhatian kepada mandat dan lingkungan eksternalnya dapat dipikirkan sebagai perencanaan dari luar ke dalam (the outside in). Perhatian kepada misi dan nilai-nilai maupun lingkungan internal dapat dianggap sebagai perencanaan dari dalam ke luar (the inside out).

Ketujuh, yaitu merumuskan strategi untuk mengolah informasi dari isu-isu yang telah didapat. Strategi diidentifikasikan sebagai pola tujuan, kebijakan, program, tindakan, keputusan atau alokasi sumber daya yang menegaskan bagaimana organisasi harus mengerjakan hal itu. Strategi yang diterapkan organisasi satu dengan lainya dapat berbeda-beda sesuai dengan tingkat, fungsi, dan kerangka waktu yang diterapkan. 
Kedelapan, merumuskan suatu visi organisasi yang efektif untuk waktu yang akan datang. Langkah terakhir dalam proses perencanaan, organisasi mengembangkan deskripsi mengenai bagaimana seharusnya organisasi itu bertindak sehingga berhasil mengimplementasikan strateginya dan mencapai seluruh potensinya. Dari praktiknya, kedelapan langkah perencanaan strategis tersebut di atas juga harus memperhatikan hal-hal sebagai berikut:

1. Strength (kekuatan), yaitu strategi ini dibuat berdasarkan jalan pikiran organisasi dengan memanfaatkan keseluruhan kekuatan untuk memaksimalkan dan memanfaatkan kekuatan yang dimiliki organisasi.

2. Weakness (kelemahan), yakni strategi yang diterapkan dalam suatu organisasi haruslah berdasar pada kegiatan yang bersifat defensif dan berusaha meminimalisir kelemahan yang ada serta menghindari ancaman yang diprediksikan bisa terjadi.

3. Opportunity (peluang), yakni strategi yang diterapkan haruslah berdasarkan pada pemanfaatan peluang yang ada dengan cara maminimalisir kelemahan yang ada serta menghindari ancaman.

4. Threats (ancaman), yakni strategi dalam menggunakan kekuatan yang dimiliki oleh organisasi untuk mengatasi ancaman.

Dengan melihat keempat hal di atas, maka dapat diambil kesimpulan, dengan memperhatikan SWOT tersebut, bahwa sebuah organisasi akan dapat menjalankan program-program yang telah disusun dan memperoleh hasil yang dikehendaki oleh organisasi.

\section{Konsep Dasar Deradikalisasi Agama}

Tidak dapat dipungkiri sebagai seorang Muslim, kita dituntut untuk senantiasa menyiarkan dan menyebarkan syariat Allah di muka bumi ini. Dalam agama Islam hal tersebut dikenal dengan istilah amar ma'ruf nahi munkar (perintah untuk melaksanakan kebaikan dan meninggalkan keburukan). Amar ma'ruf nahi munkar yang merupakan penjelmaan dan pengejawantahan dari intisari dakwah, adalah suatu kewajiban bagi 
semua orang Islam. ${ }^{34}$ Hal tersebut sesuai dalam al-Qur'an Surat Ali 'Imron ([3]: 104) sebagai berikut.

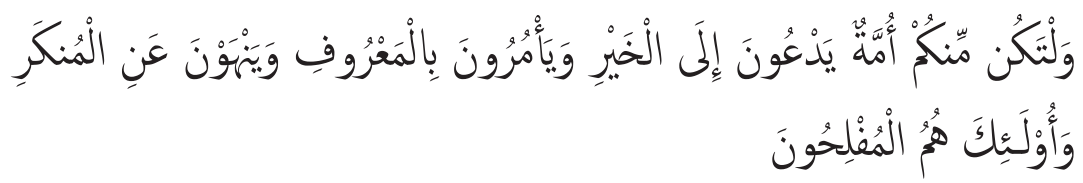

Dan hendaklah ada di antara kamu segolongan umat yang menyeru kepada kebajikan, menyuruh kepada yang ma'ruf dan mencegah dari yang munkar, merekalah orang-orang yang beruntung.

Ketika dakwah telah menggejala dan menuntut aplikasinya, maka setiap elemen masyarakat atau organisasi masyarakat (Ormas) yang mempunyai misi dakwah, mencoba menginterpretasikan ayat tersebut sesuai dengan apa yang mereka pelajari dan ketahui, sesuai dengan aliran dan faham yang mereka anut. Di sinilah awal mula permasalahan yang dimungkinkan dapat menyulut aksi radikal yang berkedok "agama". Penjelmaan Ormas-ormas yang menampakkan dirinya dengan kajian baik al-Qur'an maupun Hadis secara apa adanya (tekstualis), seperti kelompok yang tergabung dalam Ikhwanul Muslimin Indonesia (IMI), Hizbut Tahrir Indonesia (HTI), Negara Islam Indonesia (NII), pada realitanya kelompok inilah yang sering melakukan aksi-aksi radikal, dan harus diantisipasi, serta ditangani keberadaannya agar tidak menimbulkan aksi yang meresahkan. Menurut Amirsyah, sebenarnya yang menjadi acuan dari konsepsi dasar dilakukannya suatu tindakan penanganan terhadap radikalisasi agama yang ada selama ini kurang lebih didasarkan pada paradigma berikut: ${ }^{35}$

\footnotetext{
${ }^{34}$ Menurut Aminuddin Sanwar, kadar kewajiban untuk melakukan amar ma’ruf nahi munkar haruslah disesuaikan dengan porsi kemampuan atau kekuatan (jabatan/ kewenangan) masing-masing individu. Hal tersebut mengacu pada Hadis Nabi yang diriwayatkan oleh Imam Muslim. Dan hal demikian yang tampaknya kurang diperhatikan oleh kaum radikalis, sehingga mereka dalam berdakwah hanya dari segi subjektivitas kebenaran yang mereka yakini sendiri.Mengenai kewajiban dan dan Hadis tersebut dapat dilihat dalam Aminuddin Sanwar, Pengantar Ilmu Dakwah (Semarang: Fakultas Dakwah IAIN Walisongo, 1986), 5.

${ }^{35}$ Amirsyah, Meluruskan Salah Faham Terhadap Deradikalisasi: Pemikiran, Konsep,
} 
1. Pancasila sebagai Landasan Idiil. Pancasila sebagai dasar Negara dan falsafah bangsa tentunya mengikat dan mempunyai kekuatan dalam mengidentifikasi dan memecahkan masalah yang ada. Dalam hal ini NU yang turut selalu mendukung dan memperjuangkan penerapan Pancasila sebagai asas Negara, bukan piagam Jakarta, mempunyai peranan yang sangat strategis dalam penanganan deradikalisasi, baik di tingkat pusat sampai wilayah ataupun kota.

2. UUD 1945. Dalam Undang-Undang Negara Republik Indonesia tersebut, khususnya pada pasal $28 \mathrm{E}$ ayat 1 disebutkan, "Setiap orang berhak memeluk agama dan beribadah menurut agamanya memilih pendidikan da pengajaran, memilih pekerjaan, memilih kewarganegaraan, memilih tinggal di wilayah Negara dan meninggalkanya serta berhak kembali."

Pasal tersebut adalah mengindikasikan kebebasan beribadah dan memeluk agama guna dijadikan landasan dari penanganan dan penyelesaian deradikalisasi agama yang ada. Sejatinya konsepsi tentang deradikalisasi agama tidak akan muncul melainkan berangkat dari radikalisasi agama. Radikalisasi agama dalam akidahnya sering menghalalkan suatu cara untuk mencapai suatu tujuan, baik itu menggunakan teror fisik atau teror mental seperti sweeping dan penutupan hiburan malam ketika bulan Ramadan. Akan tetapi, penanganan tindak radikal yang bernuansa agama dengan menggunakan hard power approach (pendekatan kekuatan) oleh pihak aparat, seperti yang dilakukan oleh Densus 88 anti teror, bukan merupakan jawaban yang tepat untuk menyelesaikan akar persoalan radikalisme agama yang ada. Hal tersebut terbukti lebih dari 50 tahun Indonesia yang tak kunjung selesai menangani kasus DI/NII. Setelah penanganan kasus radikalisasi yang bernuansa agama menggunakan pendekatan hard measure dirasa tidak berhasil, maka pemerintah Indonesia secara sistemik, yaitu mencanangkan program penanganan menggunakan pendekatan soft approach yang dioperasikan oleh BNPT (Badan Nasional Penanggulangan Terorisme) yang sekarang ini lebih 
dikenal dengan istilah deradikalisasi.

\section{Ciri-ciri, Sejarah, dan Pemicu Radikalisasi Agama}

Secara etimologis, radikalisasi merupakan serapan dari bahasa Latin yaitu radix yang artinya akar. Dalam bahasa Ingris radical dapat berarti ekstrem, menyeluruh, fanatik, revolusioner dan fundamental. Pada awalnya istilah radikalisme agama justru diintrodusir dari tradisi Barat, terutama yaitu di kalangan keagamaan Kristen Protestan AS sekitar tahun 1910-an. Dalam perkembanganya, seperti disampaikan oleh Roger Garaudy yang merupakan filosof dari Perancis menyatakan bahwa radikalisme tidak hanya berkisar pada faham keagamaan, akan tetapi istilah tersebut telah menjelma dalam kehidupan sosial, politik, dan budaya. Dengan demikian, berarti setiap ideologi atau pemikiran yang mempunyai dampak negatif (side effect) yang dapat membawa seseorang menjadi militan dan fanatik maka hal tersebut dapat dikategorikan ke dalam radikalisme. ${ }^{36}$

Dari pengertian tersebut di atas, dapat dipahami bahwa berbagai ideologi yang ada, seperti liberalisme, Marxisme, Leninisme, dan sebagainya, dapat dipahami sebagai fundamentalisme atau radikalisme. Dengan demikian, cakupan dari istilah radikalisme ini tergantung dari mana kita melihat dan mengkajinya, yang dalam penelitian ini yaitu dibatasi dalam lingkup agama dalam hal ini agama Islam.

Pada hakikatnya faham radikalisme terhadap suatu agama adalah tidak merupakan suatu masalah yang menjadi momok dan menakutkan selama masih dalam koridor pemikiran (ideologis) para pengikutnya. Akan tetapi, ketika ideologi tersebut telah bergeser dan menjelma menjadi gerakan-gerakan yang menimbulkan keresahan, kekerasan, dan masalah lain yang dapat mengganggu stabilitas masyarakat dan memporakporandakan tatanan yang sudah ada, maka di sinilah radikalisasi agama yang timbul perlu mendapatkan perhatian bersama. Hal tersebut karena

${ }^{36}$ A. Rubaidi, Radikalisme Islam, Nahdlatul Ulama: Masa Depan Moderatisme Islam di Indonesia (Surabaya: PWNU Jawa Timur, 2010), 30-32. 
fenomena-fenomena sebagaimana disebutkan, perbedaan persepsi dan pemahaman terhadap nilai-nilai agama, akan dapat menyebabkan suatu konflik. Bahkan pada level yang lebih tinggi dapat memunculkan kekerasan antara dua kelompok yang berbeda pemahaman tersebut.

Jika dianalisa di antara penyebab yang menyulut aksi radikalisme yang bernuansa agama, bermula dari persoalan domestik sampai persoalan internasional yang memojokkan kelompok tertentu. Dalam wilayah agama, konsepsi ajaran yang berbeda dengan kenyataan, seperti semakin menjamurnya tempat-tempat hiburan yang digunakan sebagai ajang maksiat, kiai sebagai pemuka agama yang mestinya dihormati akan tetapi malah sebaliknya, seperti pembantaian kiai seperti terjadi di Poso (25 Desember 1998).

Dalam kasus di atas, aparat pemerintah sebagai pengayom seluruh elemen warganya juga malah terkesan lalai dan tidak konsisten di dalam menerapkan nilai dan norma yang telah disepakati bersama. Hadirnya organisasi keagamaan seperti NU, Muhammadiyah, dan MUI yang tidak dapat merealisasikan nilai-nilai ideal dan memecahkan masalah agama juga bisa menjadi penyebab munculnya radikalisasi agama yang ada. Di sisi lain tuntutan untuk menjalankan nilai-nilai agama harus mereka aplikasikan dalam kehidupan sehari-hari. Dalam lingkup internasional realitas politik standar ganda yang diterapkan oleh Amerika dan sekutunya juga turut memicu berkembangnya radikalisme agama saat ini. ${ }^{37}$

Penyebutan radikal terhadap kelompok yang memiliki karakter dan pola umum sebagai sebuah gerakan yang menginginkan ditegakkanya syari'at Islam secara terminologi sebagaimana disebutkan oleh Kallen setidaknya memiliki tiga karakteristik. ${ }^{38}$ Pertama, radikalisasi muncul sebagai respons yang berupa evaluasi, penolakan atau perlawanan terhadap kondisi yang sedang berlangsung, yang berupa asumsi nilai sampai dengan lembaga agama atau negara. Kedua, radikalisasi selalu berupaya

${ }^{37}$ Turmudi, Islam dan Radikalisme, 1-6.

${ }^{38}$ Umi Sumbulah, Islam Radikal dan Plularisme Agama: Studi Kontruksi Sosial Aktivis Hizb al-Tahrir dan Majelis Mujahidin di Malang tentang Agama Kristen dan Yahudi (Jakarta: BALITBANG RI, 2010), 42. 
mengganti tatanan yang sudah ada dengan sebuah tatanan baru yang disistematisir dan dikonstruksi melalui world view (pandangan dunia) mereka sendiri. Ketiga, kuatnya keyakinan akan ideologi yang mereka tawarkan. Hal tersebut rentan memunculkan sikap emosional yang potensial melahirkan kekerasan.

Berdasarkan karakteristik sebagaimana disebutkan Kallen di atas, Islam radikal dapat didefinisikan sebagai suatu kelompok yang berupaya menjadikan al-Qur'an dan Hadis sebagai basic values (nilai dasar) dari segala aspek kehidupan. Melihat epistemologi radikalisme seperti yang dideskripsikan di atas, Rubaidi yang mengadopsi istilah Martin E. Marty, mensinyalir radikalisme agama memiliki ciri-ciri sebagai berikut. ${ }^{39}$

Pertama, fundamentalisme, menurutnya hal ini dipahami sebagai gerakan perlawanan yang dalam banyak kasus biasanya dilakukan secara radikal, yang demikian merupakan respons dari ancaman yang bisa membahayakan eksistensi dari suatu agama. Bentuk ancaman yang mereka sinyalir bisa mengganggu eksistensi agama mereka, seperti modernisasi, sekularisasi, serta tatanan nilai Barat lainya. Adapun acuan yang digunakan mereka adalah bersumber dari kitab suci versi mereka. Dengan demikian, gerakan perlawanan yang dilakukan para aktivis gerakan Islam fundamentalis sejatinya merupakan tindakan subjektif-individual yang dibangun berdasarkan nilai-nilai kolektif yang berkembang dalam sebuah gerakan. Tindakan subjektif yang dimaksud dapat berupa tindakan nyata yang diarahkan baik kepada pihak tertentu atau agama lain maupun tindakan yang bersifat membatin dan sangat subjektif, baik berupa pengetahuan, pemahaman, maupun persepsinya. ${ }^{40}$

Kedua, penolakan terhadap hermeneutika. Hal ini dapat dimaknai bahwa kaum radikal menolak terhadap sikap kritis teks agama dan segala bentuk interpretasinya. Teks-teks al-Qur'an hanya dimaknai apa adanya. Kitab suci dimaknai benar adanya tanpa mempertimbangkan rasionalitas (nalar) dan sabab nuzul ayat sehingga dalam implementasinya

\footnotetext{
${ }^{39}$ Turmudi, Islam dan Radikalisme, 35-37.

${ }^{40}$ Umi Sumbulah, Konfigurasi Fundamentalisme Islam (Malang: UIN Malang Press, 2009), 22.
} 
mereka harus mengamalkan al-Qur'an secara literal sesuai dengan apa yang tertera tanpa pertimbangan akal.

Ketiga, penolakan terhadap pluralisme dan relativisme. Bagi kaum radikal pluralisme merupakan pemahaman yang keliru terhadap teksteks kitab suci. Intervensi nalar terhadap al-Qur'an dan perkembangan sosial kemasyarakatan yang telah lepas dari kendali agama, serta pandangan yang tidak sejalan dengan kaum radikalis adalah potret dari bentuk relativisme keagamaan yang ada.

Keempat, penolakan terhadap perkembangan historis dan sosiologis. Perkembangan ini dinilai oleh kaum radikalis sebagai muara ketidaksesuaian dalam keberagamaan, mereka menilai bukan al-Qur'an yang harus mengikuti nalar, akan tetapi akallah yang seharusnya tunduk dan patuh terhadap semua nilai-nilai al-Qur'an dalam menginterpretasi nilainilai agama.

Maraknya gerakan Islam radikal, yang oleh Rubaidi disebut dengan gerakan fundamentalisme Islam, di Indonesia sejatinya telah mengalami perkembangannya sejak tahun 1980-an. Hal tersebut ditandai dengan munculnya fenomena menguatnya religiositas umat Islam. Ekspresi gerakan ini semakin terbuka, tidak seperti gerakan sempalan, yang oleh Bruinessen didefinisikan sebagai gerakan yang menyimpang atau memisahkan diri dari ortodoksi (penerapan ajaran murni) yang berlaku. Untuk memahami gejala radikalisme agama yang ada, menurut Umi Sumbulah setidaknya terdapat dua pendekatan yang bisa digunakan, yaitu dari segi objektivitas dan subjektivitas.

Dari segi objektivitas, dapat dipahami bahwa pemicu munculnya radikalisme agama adalah karena teks-teks agama memberikan legitimasi dan menganjurkan hal demikian. Dalam konteks ini jelas kita tahu bahwa dalam pandangan Islam, agama-agama selain Islam seperti Kristen dan Yahudi adalah musuh. Asumsi demikian tentunya telah membuka cakrawala bagi para pengikutnya, bahwa dalam upaya berdakwah dan menyebarkan nilai-nilai agama, seolah-olah mereka diperkenankan menggunakan jalan kekerasan ataupun jalan lain seperti permusuhan. Padahal, hal demikian adalah salah kaprah, hal tersebut dapat dicon- 
tohkan oleh Rasulullah dalam membagi golongan non-Islam ke dalam dua bagian, yaitu golongan harbi dan kafir dzimmi. Kafir harbi yaitu golongan yang wajib diperangi karena mereka melawan terhadap kepemimpinan Islam di wilayah Rasul. Sedangkan golongan yang dinamakan dengan kafir dzimmi, yaitu golongan yang wajib dilindungi karena mereka taat dan mau membayar jizyah (pajak).

Dari segi subjektivitas, setiap individu sebagai subjek yang aktif telah mendefinisikan hidupnya dengan dunia luar, dan mengimplementasikan ajaran yang ia dapat dalam kehidupanya. Hal tersebut telah memberikan makna bahwa gejala radikalisme tidak hanya dipahami dari teks agama, tetapi juga harus dicermati dari dunia luar yang telah menjadi entitas yang turut mempengaruhi seseorang dalam menginternalisasikan agamanya. ${ }^{41}$ Dengan demikian, timbulnya radikalisme agama ternyata tidak hanya murni dari interpretasi ajaran agama saja, akan tetapi radikalisme agama juga bisa disebabkan oleh struktur sosial, ekonomi, dan politik.

Tidak dapat dipungkiri bahwa sikap fanatik, intoleran dan eksklusif ditengarai sebagai pemicu munculnya radikalisme agama. Ketika kita lacak akar pemicu munculnya faham radikal terhadap ajaran agama secara lebih umum dalam agama Islam, sikap-sikap tersebut sejatinya telah ditampakkan pertama kali oleh kaum Khawarij. Pada mulanya kelompok ini adalah merupakan pengikut dari Khalifah Ali bin Abi Thalib atau yang kita kenal dengan kelompok Syỉah.

Fenomena munculnya kaum Khawarij adalah berawal dari terjadinya Perang Siffin, yaitu peperangan yang terjadi antara pasukan Khalifah Ali bin Abi Thalib melawan Muawiyah yang terjadi pada tahun ke-37 Hijriyah atau 648 Masehi. Ketika perang sedang berlangsung dan kelompok Ali hampir memenangkan peperangan, kemudian Muawiyah yang dikenal dengan orang yang cerdik menawarkan perundingan damai atau yang dikenal dengan istilah tahkim sebagai jalan penyelesaian permusuhan.

Ali yang dikenal dengan sosok yang arif kemudian menerima

\footnotetext{
${ }^{41}$ Ibid., 43.
} 
tawaran tahkim yang diajukan oleh Muawiyah. Akan tetapi, di sisi lain, ternyata kesediaan Ali untuk menerima tahkim kepada pihak Muawiyah telah mengakibatkan 4.000 pasukan pengikutnya memisahkan diri dan membentuk kelompok baru yang kemudian dikenal dengan nama Khawarij. Mereka menolak perundingan dan menginginkan permusuhan yang terjadi di antara mereka haruslah diselesaikan dengan kehendak Tuhan, bukan lewat perundingan. Kaum Khawarij menganggap bahwa penyelesaian peperangan menggunakan perundingan adalah telah melawan kehendak Tuhan. Atas dasar inilah kemudian kaum Khawarij mengkafirkan (takfir) tarhadap kelompok Ali dan Muawiyah. Selain itu, mereka juga menggangap kafir terhadap mayoritas kaum Muslimin yang moderat dan menuduhnya sebagai pengecut.

Bagi kaum Khawarij, orang-orang yang ia anggap kafir sekalipun adalah orang Islam dianggapnya sebagai orang-orang yang halal darahnya, mereka boleh dibunuh, dan dimusnahkan dari muka bumi ini. Atas dasar itulah kaum Khawarij kemudian melakukan propaganda, kekerasan, dan berbagai motif teror terhadap orang Islam yang tidak sependapat dengan mereka. Mereka juga memasukkan jihad sebagai rukun iman, ${ }^{42}$ Ali pun dibunuh oleh seorang Khawarij yang bernama Ibnu Muljam sewaktu Ali shalat subuh.

Pada akhirnya pola pemikiran dan sikap keagamaan model Khawarij inilah yang kemudian diteruskan dan dikembangkan oleh paham Wahabi di Arab Saudi, yaitu mulai abad ke-12 H atau ke-18 M yang dipelopori oleh Muhammad bin Abdul Wahab. Lebih spesifik lagi radikalisme agama yang terjadi di Indoesia menurut Van Bruinesen yang ia sebut sebagai "Islam radikal" dapat dilacak pada munculnya Darul Islam (DI) dan partai berbagai macam partai politik seperti Majelis Syura Muslimin Indonesia (Masyumi) yang ada di berbagai kota di Indonesia.

Darul Islam (DI) membangun fragmen kelompoknya dengan kekuatan militer. Beberapa pemberontakan pun terjadi di berbagai wilayah di tanah air, seperti di Sulawesi Selatan (Kahar Muzakkar), Kali-

\footnotetext{
${ }^{42}$ Rahimi Sabirin, Islam dan Radikalisme (Jakarta: Athoyiba, 2004), 6-8.
} 
mantan Selatan (Ibnu Hajar), Aceh (Daud Beureuh), dan di Jawa Barat (Kartosuwiryo). Dengan kekuatan ini, DI melancarkan pemberontakan kepada pemerintah Republik Indonesia secara terbuka, kendatipun kemudian dapat diberangus oleh rezim politik waktu itu. Sedangkan Masyumi membawa gagasan Islam dalam kerangka kenegaraan di parlemen dan sejarah mencatatnya berhasil menduduki peringkat kedua pada Pemilu tahun 1955.

Di Indonesia awal mula munculnya Islam sebagai kekuatan politik adalah merupakan transformasi dari kekuatan ekonomi umat yang ditujukan untuk melawan hegemoni ekonomi China dan kolonial di pasar lokal. Konteks kemunculan Sarekat Islam (SI) bermula dari H. Samanhudi, yang mempersatukan kepentingan ekonomi umat Islam ke dalam satu wadah, yang akhirnya bertransformasi menjadi satu partai politik. Awal kemunculan Sarekat Islam bermula dari inisiatif dari pedagangpedagang Muslim untuk melindungi kepentingan dagang mereka dari ekspansi China. Pada perkembangan berkutnya SI pasca Tjokroaminoto terfragmentasi menjadi SI-Merah yang kemudian menjelma menjadi Partai Komunis Indonesia (PKI). ${ }^{43}$

Dari berbagai fenomena yang melatarbelakangi munculnya radikalisme agama di Indonesia, dapat diketahui bahwa sejarah umat Islam di Indonesia terjadi akibat pergolakan kepentingan-kepentingan mereka yang termarjinalkan. Hal tersebut dapat terlihat pada rezim Orde Baru yang mengambil alih peran sebagai pemilik sumber daya dan secara represif telah melakukan subordinasi kepada kelompok-kelompok yang berpotensi menjadi oposisi terhadap sentralisme peranan negara. Kemunculan gerakan-gerakan Islam yang dinilai radikal pada era Orde Baru, melalui perangkat-perangkat birokrasinya mulai dari aparat sipil sampai militer telah mentransformasikan diri menjadi rezim otoritarian dengan cara menindas kekuatan-kekuatan yang berpotensi menjadi oposisi. Seperti ideologi komunisme dijadikan sebagai ideologi terlarang,

\footnotetext{
${ }^{43}$ Ahmad Rizky M. Umar, "Melacak Akar Radikalisme Islam di Indonesia," Jurnal Ilmu Sosial dan Ilmu Politik, FISIP UGM Yogyakarta, No. 2, Vol.14 (November 2010), 173.
} 
sedangkan nasionalisme yang merupakan ideologi terkuat pasca tahun 1955, dipersempit ruang geraknya dengan cara membungkam hak politik tokoh-tokohnya.

Kemudian untuk melakukan subordinasi terhadap kekuatan Islam inilah maka lahir diskursus dengan apa yang dinamakan dengan "Islam Radikal". Pada rezim Orde Baru kasus yang pertama kali mencuat yaitu Komando Jihad yaitu tepatnya pada pembajakan pesawat Woyla, dan inilah yang disinyalir sebagai aksi terorisme pertama kali yang ada di Indonesia. ${ }^{44}$ Jika kita lihat dengan kacamata ekonomi dan politik, seting Orde Baru yang berkarakter sangat kuat, dengan ideologi developmentalisnya telah mengakibatkan kelompok kelas pekerja yang miskin merasa termarjinalkan oleh rezim tersebut dan kemudian muncul ke permukaan untuk melakukan perlawanan. Situasi marjinal seperti ini telah mengakibatkan mereka menjadi radikal dengan keyakinan agama Islam yang dianutnya. Akan tetapi, jumlah ini tidak seberapa dibanding dengan kelompok kelas menengah yang terlempar dari lingkaran kekuasaan karena mereka memiliki idealisme yang berbasis agama yang cukup kuat. Kemudian, mereka mengkoordinasikan diri ke dalam gerakan sosial dan bergabung dengan kelompok lain dengan menggunakan Islam sebagai landasan dalam berjuang. Adapun tujuanya ialah menggulingkan dan menghancurkan tirani rezim politik yang telah membuat mereka termarjinalkan. Menurut Vedi R. Hadiz aksi terorisme yang merupakan dampak dari adanya radikalisme agama di berbagai lini kehidupan merupakan wujud perlawanan kelas yang termarjinalkan oleh oligarki kelas pemilik modal (borjuasi) dan modal. Subordinasi atas kelas marjinal dalam kasus yang terjadi di Indonesia yang dalam hal ini adalah gerakan politik Islam telah membawa kesadaran kelas untuk merebut kembali peran Negara yang telah dianggap gagal dalam mewujudkan kesejahteraan terhadap rakyatnya.

Dari berbagai fenomena yang melatarbelakangi terbentuknya radikalisme agama seperti tersebut di atas, penulis menggari bawahi bahwa sejatinya keberadaan apa yang disebut Islam radikal di Indonesia berbeda

\footnotetext{
${ }^{44}$ Ibid., 175.
} 
dengan apa yang terjadi di Timur Tengah, dengan kata lain keterkaitan itu hanya dalam kapasitas kesamaan visi dan persepsi mengenai perubahan sosial dalam kerangka hukum politik Islam. Artinya, kemunculan Islam radikal tidak lagi dipahami dengan Wahabisme atau Islam Transnasional, akan tetapi Islam radikal tidak lebih dari sekadar simbol ketidakpercayaan terhadap rezim otoriter yang berkuasa yang telah membungkam suara rakyat.

\section{Penutup}

Deradikalisasi adalah bagian dari strategi kontra radikal sebagai upaya dalam bentuk strategis dan taktis untuk memotong seluruh variabel yang dipandang sebagai stimulan lahirnya tindakan radikalisme baik yang dilakukan sebelum ataupun setelahnya. ${ }^{45}$ Radikalisasi agama yang menggejala saat ini, tidak bisa terlepas dari apa yang dinamakan dengan "politik identitas". Adanya eksistensi dan gejala imperialisme global melalui sikap Barat, khususnya kebijakan politik Amerika dalam merancang bangun perpolitikan dunia dengan memperlakukan dunia Islam secara hegemonik. Dari pengertian di atas, dapat dipahami bahwa tindak radikalisasi yang bernuansa agama ketika telah menjurus ke dalam hal-hal yang bersifat "anarkis" dan "mengganggu orang lain" sejatinya menjadi hal yang penting untuk diselesaikan secara bersama. Mengingat upaya penanganan deradikalisasi dan deideologisasi merupakan tanggung jawab kolektif, terutama sinergisitas para tokoh agama, kepolisian, dan pemerintah.

Proses deradikalisasi hendaknya dilakukan tidak hanya melibatkan aparat saja, akan tetapi juga harus melibatkan tokoh masyarakat, dan lembaga-lembaga yang ada. Setidaknya strategi deradikalisasi agama yang diterapkan harus mengacu pada tiga langkah strategi, yaitu langkah prevention (pencegahan), rehabilitation (rehabilitasi), dan aftercare (pem-

\footnotetext{
45 "Latar Belakang Munculnya Strategi Deradikalisasi," www.eramuslim.com/berita/ analisa/latar-belakang-munculnya-strategi deradikalisasi.htm. Diakses pada 2 April 2018.
} 
binaan pasca pelepasan).

Selain itu, ada lima gagasan dalam pribumisasi Islam. Pertama, kontekstual, yaitu Islam dipahami sebagai ajaran yang terkait zaman dan tempat. Kedua, toleran, sikap toleran dalam beragama dan toleran terhadap perbedaan penafsiran dapat menumbuhkan kesadaran untuk bersikap. Ketiga, menghargai tradisi, Islam dibangun di atas penghargaan pada tradisi lama yang baik, karena sesungguhnya Islam tidak memusuhi tradisi lokal melainkan budaya tersebut dijadikan sebagai sarana dakwah Islam. Hal tersebut seperti yang dilakukan oleh Walisongo dalam penyebaran agama Islam di Indonesia. Keempat, progresif, dengan perubahan terhadap praktik keagamaan dimana ia berada. Kelima, membebaskan, di sini Islam sebagai suatu agama yang dapat menjawab problematika kemanusiaan yang ada secara universal tanpa membedakan agama dan etnik. Dengan semangat pembebasan tersebut, Islam sebagai agama yang rahmatan lil 'alamin harus siap melawan penindasan, kemiskinan, keterbelakangan, anarki sosial, dan sebagainya.

\section{DAFTAR PUSTAKA}

Abdalla, Ulil Abshar. Menyegarkan Kembali Pemikiran Islam: Bunga Rampai Surat-surat Tersiar. Jakarta: Nalar, 2007.

Abi Zakariya, Imam Muhyiddin. Riyadlussolihin: Min Kalami Sayyidil Mursalin. Beirut: Daarul Khoir, 1999.

Amirsyah. Meluruskan Salah Faham Terhadap Deradikalisasi; Pemikiran, Konsep, dan Strategi Pelaksanaan. Jakarta: Grafindo Hazanah Ilmu, 2012.

Ahmad, Baso. NU Studies: Pergolakan Pemikiran antara fundamentalisme Islam dan Fundamentalisme Neo-Liberal. Jakarta: Penerbit Erlangga, 2006.

Anas, Ahmad. Paradigma Dakwah Kontemporer: Aplikasi Teoretis dan 
Praktis Dakwah Sebagai Solusi Problematika Kekinian. Semarang: Pustaka Rizki Putra, 2006.

Bahri, Fathul. Meniti Jalan Dakwah: Bekal Perjungan Para Da’i. Jakarta: Sinar Grafika, 2008.

Hadrawi, Nawawi. Metodologi Penelitian Bidang Sosial. Yogyakarta: Gadjah Mada University Press, 1999.

Hidayatulah, Syarif. Islam Isme-isme; Aliran dan Paham Islam di Indonesia. Yogyakarta: Pustaka Pelajar, 2010.

Ida, Laode. Kaum Progresif dan Sekularis Baru. Yogyakarta: Penerbit Erlangga, 2004.

Khamami, Zada. Islam Radikal: Pergulatan Ormas-Ormas Islam Garis Keras di Indonesia. Jakarta: Teraju, 2002.

Miftahuddin M. Perencanaan Strategis Sebagai Organisasi Sosial (Strategic Planning for Public and Nonprofit Organizations: A Guide Strengthering and Sustaining Organizational Achievement, terj. Jhon M Bryson). Cet. IV. Yogyakarta: Pustaka Pelajar, 2001.

Munir, M. \& Ilaihi Wahyu. Manajemen Dakwah. Jakarta: Kencana, 2006.

Natsir, Mohammad. Fiqhud Da’wah. Jakarta: Media Da’wah, 2000.

Nawawi, Hadari. Manajemen Strategik: Organisasi Non Profit Bidang Pemerintahan dengan Ilustrasi di Bidang Pendidikan. Yogyakarta: Gadjah Mada University Press, 2005.

Pribadi, Abdurrahman, et.al. Membongkar Jaringan Terorisme. Jakarta: Abdika Press, 2009.

Prasetyo, Eko, et.al. Memahami Wajah Para Pembela Tuhan. Yogyakarta: Interfidei, 2004.

Pimay, Awaludin. Paradigma Dakwah Humanis Strategi dan Metode Prof. K.H. Saefudin Zuhr. Semarang: Rasail, 2005.

Metodologi Dakwah: Kajian Teoretis dari Khazanah al-Qur'an. Semarang: Rasail, 2006. 
P. Siagian, Sondang. Analisis serta Perumusan Kebijaksanaan dan Struktur Organisasi. Jakarta: CV. Haji Masagung, 1994.

Syabibi, M. Ridlo. Metodologi Ilmu Dakwah: Kajian Ontologis Dakwah Ikhwan al-Safa. Yogyakarta: Pustaka Pelajar, 2008.

Rubaidi, A. Radikalisme Islam, Nahdlatul Ulama: Masa Depan Moderatisme Islam di Indonesia. Jatim: PWNU Jawa Timur, 2010.

Sabirin, Rahimi. Islam dan Radikalisme. Jakarta: Athoyiba, 2004.

Shihab, M. Quraisy. Tafsir al-Misbah: Pesan, Kesan, dan Keserasian alQur'an. Jakarta: Lentera Hati, 2002.

Sanwar, Aminuddin. Pengantar Ilmu Dakwah. Semarang: Fakultas Dakwah, 1986.

Shihab, Alwi. Membedah Islam di Barat: Menepis Tudingan Meluruskan Kesalahpahaman. Yogyakarta: Andi Offset, 2004.

Simuh. Islam dan Pergumulan Budaya Jawa. Bandung: Mizan, 1998.

Sulthon, Muhammad. Desain Ilmu Dakwah. Yogyakarta: Pustaka Pelajar, 200.

Syam, Nur. Radikalisme dan Masa Depan Agama: Rekontruksi Tafsir Sosial Agama, dalam M. Ridwan Nasir. Surabaya: IAIN Press, 2001.

Sumbulah, Umi. Konfigurasi Fundamentalisme Islam. Malang: UIN Malang Pres, 2009.

. Islam Radikal dan Plularisme Agama: Studi Kontruksi Sosial Aktivis

Hizb al-Tahrir dan Majelis Mujahidin di Malang tentang Agama Kristen dan Yahudi. Jakarta: Balitbang RI, 2010.

Syu'aibi, Ali. Meluruskan Radikalisme Islam. Ciputat: Pustaka Azhary, 2004.

Turmudzi, Endang, et.al. Islam dan Radikalisme di Indonesia. Jakarta: Lipi Press, 2005.

Umar, Ahmad Rizky M. "Melacak Akar Radikalisme Islam di Indonesia." Jurnal Ilmu Sosial dan Ilmu Politik. Fisip UGM Yogyakarta. No. 2, 
Vol. 14 (November 2010).

az-Zuhaili, Wahba. Al-Tafsiiru al-Muniiru: Fi al-Aqidah, wa As-Syariah wa al-Manhaj. Beirut: Darul Fikri, 1991.

\section{Sumber Internet:}

http://www.eraMuslim.com/berita/analisa/latar-belakang-munculnyastrategideradikalisasi.htm.

http://budisansblog.blogspot.com/2011/11/deradikalisasi-berbasispesantren.html.

http://wartapedia.com/nasional/hukum-dan-kriminal/4334-radikalisme10-jaksasiapkansusunan-dakwaan-tersangka-nii.html.

http://wartapedia.com/nasional/hukum-dan-kriminal/4334-radikalisme10-jaksasiapkan-susunan-dakwaan-tersangka-nii.html http:// wartapedia.com/nasional/hukum-dan-kriminal/4334-radikalisme10-jaksasiapkan-susunan-dakwaan-tersangka-nii.html.

Sidqi, Ahmad dalam "Deradikalisasi Melalui Pesantren” diakses dari http://budisansblog.blogspot.com/2011/11/deradikalisasi-berbasispesantren.html. 
